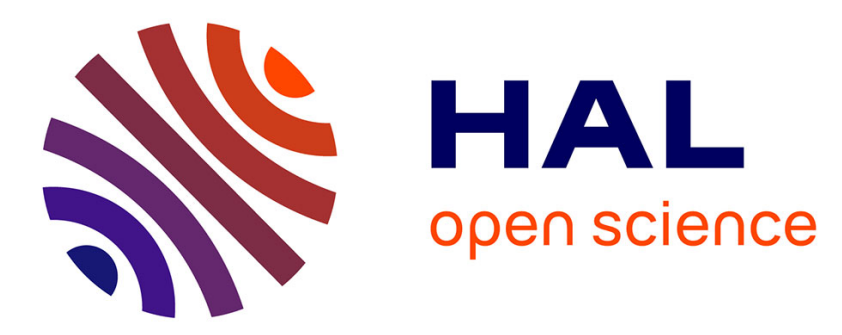

\title{
Atypical epithelial hyperplasia of the breast: state of the art
}

L. Dion, A. Racin, S. Brousse, F. Beltjens, A. Cauchois, Jérémy Lévêque, C. Coutant, V. Lavoue

\section{> To cite this version:}

L. Dion, A. Racin, S. Brousse, F. Beltjens, A. Cauchois, et al.. Atypical epithelial hyperplasia of the breast: state of the art. Expert Review of Anticancer Therapy, 2016, 16 (9), pp.943-953. 10.1080/14737140.2016.1204916 . hal-01381399

HAL Id: hal-01381399

https://hal-univ-rennes1.archives-ouvertes.fr/hal-01381399

Submitted on 17 Nov 2016

HAL is a multi-disciplinary open access archive for the deposit and dissemination of scientific research documents, whether they are published or not. The documents may come from teaching and research institutions in France or abroad, or from public or private research centers.
L'archive ouverte pluridisciplinaire HAL, est destinée au dépôt et à la diffusion de documents scientifiques de niveau recherche, publiés ou non, émanant des établissements d'enseignement et de recherche français ou étrangers, des laboratoires publics ou privés. 


\section{Atypical epithelial hyperplasia of the breast: state of the art}

Ludivine Dion $^{\mathrm{a}^{*}}$, Adelaïde Racin ${ }^{\mathrm{a}^{*}}$, Susie Brousse $\mathrm{a}^{\mathrm{a}^{*}}$, Françoise Beltjens $^{\mathrm{e}}$, Aurélie Cauchois ${ }^{\mathrm{f}}$ Jean Levêque ${ }^{\mathrm{a}, \mathrm{b}, \mathrm{c} \#}$, Charles Coutant ${ }^{\mathrm{e}, \#}$, Vincent Lavoué ${ }^{\mathrm{a}, \mathrm{b}, \mathrm{c} \#}$

${ }^{a}$ Department of Gynaecology, Rennes University Hospital, 16 Bd de Bulgarie, BP 90243, F35203 Rennes, Cedex 2, France. University of Rennes 1, Rennes, France.

${ }^{b}$ Regional University Centre of Mastology, CRLCC Eugène Marquis Av de la Bataille Flandres Dunkerque, CS 44229, F-35402 Rennes, Cedex, France.

${ }^{c}$ ER440, Oncogenesis, Stress and Signaling, INSERM, Rennes, France.

${ }^{d}$ Department of Tumour Pathology, Georges-François Leclerc Cancer Centre - Unicancer, Dijon. University of Burgundy-Franche Comté. France.

${ }^{e}$ Department of Surgical Oncology, Georges-François Leclerc Cancer Centre - Unicancer, Dijon. University of Burgundy-Franche Comté. France.

${ }^{f}$ Department of Tumour Pathology, Rennes University Hospital, University of Rennes 1, Rennes, France

*Shared first authorship

\#Shared senior authorship 
Corresponding author: Pr Vincent Lavoué, Service de Gynécologie, CHU Anne de

Bretagne, 16 Bd de Bulgarie, BP 90 347, F-35 203 Rennes, Cedex 2 - T = 33 (0)299 267171

- F = 33 (0)299 266700 - Email: vincent.lavoue@chu-rennes.fr 


\begin{abstract}
Introduction: Atypical epithelial hyperplasia (AEH) of the breast is considered benign histological lesions with breast cancer risk. This review focuses on clinical signification and management of AEH that remains controversial.
\end{abstract}

Areas covered: A review of published studies was performed using medline database. In this review, we fully describe the current evidence available. In particular, we describe 1) data from immunohistochemistry and molecular studies that suggest AEH is a precursor of breast cancer; 2) epidemiological studies demonstrate low rate of breast cancer in women with AEH; 3) surgical excision is necessary after diagnosis of AEH, such as lobular carcinoma in situ or atypical ductal hyperplasia, on core needle biopsy; 4) although current recommendations are evolving to fewer (if not no) excisions for flat epithelial with atypia and classic lobular neoplasia found on percutaneous biopsy (without radiologic indications for excision).

Expert commentary: HEA management steel need prospective evidences, but recent retrospective data give some clue for less invasive management for some of HEA.

Key words: atypical ductal hyperplasia; columnar cell lesions with atypia; lobular neoplasia; atypical lobular hyperplasia; lobular carcinoma in situ; core needle biopsy; surgical excision; breasteancer. 


\section{1- Introduction}

The increase in the relative frequency of atypical hyperplasia $(\mathrm{AH})$ lesions of the breast coincided with the generalisation of organised breast cancer screening in France: the frequency of pure $\mathrm{AH}$ lesions in a series of surgical breast biopsies was 3.6\% in 1985 [1] and $23 \%$ in 2007 [2]. Atypical hyperplasia of the breast, considered benign histological/esions with breast cancer risk, come under the broader category of fibrocystic breast disease: the common findings are epithelial hyperplasia (i.e. proliferation of cells beyond the 2-layer architecture of the epithelium lining the lactiferous ducts and lobules) and abnormal appearance and arrangement of cells. Currently, $\mathrm{AH}$ is divided into atypical ductal hyperplasia (ADH), flat epithelial atypia (FEA) and lobular neoplasia (LN), which itself is further divided into atypical lobular hyperplasia (ALH) and lobular carcinoma in situ (LCIS) [3]. AH lesions do not included ductal carcinoma in situ (high grade or low grade), which were true precursor of invasive breast carcinoma. The clinical significance of these lesions is still subject to controversy. At the least, all are markers of breast cancer risk: women with one of these lesions have a higher risk than the general population of developing cancer in the ipsilateral and contralateral breast [4]. Some types of $\mathrm{AH}$ are not just risk markers but probably veritable precursors of invasive malignant lesions, constituting a necessary but insufficient step in the natural history of the cancer [5-8]. For these reasons, clinicians have to confront several issues: (a) discovery of such lesions on a breast specimen obtained under image guidance (and hence fragmentary in nature) raises the issue of whether the radiological signal is representative of the histology, making positive and differential diagnosis problematic for the pathologist and presenting the dilemma of whether to proceed to surgical biopsy for analysis of the whole signal; (b) uncertainty surrounding the natural history of the lesions translates into: closer surveillance if they are considered only markers of cancer risk, or surgical excision if they are considered precursor lesions; and extreme caution with regard 
to combined oestrogen-progestogen hormone treatments or even chemoprevention $[9,10])$; (c) surgery of these lesions, which are usually non-palpable, is associated with particularities with respect to their localisation, the orientation of the excised tissue following as closely as possible the histological diagnosis, and positive or negative margins depending on whether or not they are considered precursor lesions.

The present article begins with nosology of AH of the breast, then management of the lesion is described in detail for the different histological groups ( $\mathrm{ADH}, \mathrm{LN}, \mathrm{FEA})$, whether they are discovered in a percutaneous breast specimen or surgical specimen and are associated or not with an invasive lesion. The specificities of breast surgery subsequent to the discovery of pure AH on percutaneous biopsy are given. Finally, the role of menopausal hormone replacement therapy (HRT) and chemoprevention in patients with $\mathrm{AH}$ is discussed, using the international literature.

2- Materials and methods. A review of published studies was performed. Medline baseline searches were performed using the following key words: atypical ductal hyperplasia, columnar cell lesions with atypia, flat epithelial atypia, lobular neoplasia, atypical lobular hyperplasia, lobular carcinoma in situ, core needle biopsy, breast cancer, precursor lesion, hormonal replacement therapy. For each breast lesion, identified publications were assessed for clinical practice in epidemiology, diagnosis and patient management.

\section{3- Results}

\section{1- Nosology of atypical hyperplasia}


AH can be divided into three broad groups: atypical ductal hyperplasia, lobular neoplasia and flat epithelial atypia.

3.1.1 - Flat Epithelial Atypia (FEA). This pathological entity has only recently been designated as such $[3,11,12]$. Its histology corresponds to that described under other names (clinging carcinoma of the monomorphic type [13], ductal intraepithelial neoplasia of the flat monomorphic type [7], columnar cell change with atypia [11, 12], flat epithelial with atypia [3], clinging DCIS, etc.). Columnar metaplasia is a ductal neoplastic alteration in which normal luminal cells are replaced by 1 to 3-5 layers of columnar cells (cells with apical "snouts" and luminal secretions) and the terminal duct lobular unit (TDLU) shows low grade atypia (variability in cell height, higher nucleus-to-cytoplasm ratio, round nuclei with nucleoli, loss of polarity in relation to the basement membrane, etc.) [3]. Two forms of columnar metaplasia are distinguished: columnar cell change, in which acini are lined by one or two layers of modified epithelial cells; and columnar cell hyperplasia, in which acini are lined by more than two layers of epithelial cells. They may be associated with mammographically detectable microcalcifications. FEA can be distinguished from columnar cell change by the presence of cellular atypia and from $\mathrm{ADH}$ and ductal carcinoma in situ (DCIS) by the absence of architectural atypia $[11,12,14,15]$. The incidence of pure FEA was approximately $3.5 \%$ of surgical breast biopsies in 2007 [16]: it is frequently discovered secondary to BIRADS (ACR) 4 microcalcifications, which are present in 50 to $75 \%$ of cases. The biological and clinical significance of FEA is still not known with certainty. Sometimes the three forms of $\mathrm{AH}(\mathrm{FEA}, \mathrm{ADH}, \mathrm{LN})$ co-exist in a single breast surgical specimen and sometimes in the same TDLU [2, 17-21]. These 3 lesions, co-existing in a single breast surgical specimen, have similar immunophenotypical and cytogenetic profiles, such that FEA may be considered a precursor or as the first (non-obligate) morphological expression of LN and $\mathrm{ADH}$ [21]. In breast surgical specimens, FEA is also frequently associated with more 
serious lesions such as low-grade DCIS and invasive carcinomas (especially the tubular subtype). For some authors, this is sufficient to consider FEA as a precursor to invasive disease $[17,18,20,22]$. In addition, immunophenotyping studies have shown a similar expression profile between, on the one hand, FEA and, on the other hand, DCIS and invasive carcinoma lesions $[8,20,23,24]$ (high expression of oestrogen and progesterone receptors, BCL-2, low Ki-67 and well-differentiated immunohistochemical cytokeratin profile (CK5and CK18+)). Similarly, cytogenetic studies of FEA lesions associated with DCIS and invasive carcinoma lesions showed the same changes in the genetic molecular profile $[7,8$, 25]. For these authors, the continuum of phenotypical and cytogenetic lesions constitutes the basis for considering FEA to be a (non-obligate) precursor of low-grade DCIS and invasive carcinoma $[7,8,20,21,25]$ in which FEA represents the first step on the carcinogenesis pathway $[8,21]$. However, in the few series with long-term follow-up — involving 25, 101 and 59 patients followed up for 19, 10 and 5 years, respectively - the diagnosis of FEA did not lead to invasive carcinoma [13, 16, 26-30]. FEA therefore has a very low risk of becoming invasive and in light of the data from these series, it cannot be considered a precursor of breast cancer. More data are required to determine the clinical and biological significance of FEA.

3.1.2. - Atypical auctal hyperplasia $(A D H)$. $\mathrm{ADH}$ is an intraductal monomorphic cellular proliferation with some but not all of the cytological and architectural characteristics of low grade DCIS (a round nucleus and/or a stable nucleus-to-cytoplasm ratio and/or regular cellular architecture without particular organisation) [2]. There are 2 quantitative criteria that distinguish $\mathrm{ADH}$ from low-grade DCIS: the presence of homogeneous involvement of not more than 2 membrane-bound spaces; or a size of less than $3 \mathrm{~mm}$. [3, 31].

The mean age at diagnosis is 46 years. The incidence of pure ADH was approximately $2.1 \%$ of surgical breast biopsies in 1985 [1] and 12\% in 2007 [16]. This lesion is classified in the 
moderate-risk group (relative risk of 4 to 5) for breast cancer [4, 32, 33] with higher risk in those with a first-degree family history [1]. ADH has no clinical manifestations, but is associated with radiological microcalcifications; it is usually discovered fortuitously in breast tissue. The clinical and biological significance of $\mathrm{ADH}$ remains subject to controversy Cytogenetic studies of ADH have revealed the development of heterozygosity (especially 16q-) and allelic rearrangements similar to those of DCIS and invasive carcinoma, rendering $\mathrm{ADH}$ a non-obligate step in the carcinogenesis pathway $[21,34,35]$. However, epidemiological studies have shown that the natural history of this lesion does not necessarily culminate in invasion $[16,32,33]: 2$ cases of DCIS and 5 cases of invasiye carcinoma were observed after a median follow-up of 160 months in 220 patients with pure ADH on an excision specimen [16]. Therefore, this lesion is currently considered a risk marker for breast cancer for management purposes.

3.1.3 - Lobular neoplasia (LN). LN is the proliferation of small, discohesive (due to lack of ECadherin expression), monomorphic cells causing distension of the terminal duct lobular unit and possible pagetoid spread into lactiferous ducts [3]. This lesion is usually multifocal and bilateral [36, 37]. Lobular neoplasia is characterised by the absence of E-Cadherin (a transmembrane protein) staining on immunohistochemistry [3]. Lobular neoplasia refers to a spectrum of lesions formerly called atypical lobular hyperplasia (ALH) and lobular carcinoma in situ (LCIS) [36]. In ALH (3a), less than half of the lobules of a lobular unit have been invaded. In LCIS (3b), cellular proliferation affects more than half of the acini of the lobular unit [36]. Another LN dichotomy, currently enjoying widespread use, divides it into classic and pleomorphic forms. Pleomorphic lobular neoplasia is distinguished from the classic form by its pleomorphic cytological appearance (discohesive cells with large cytoplasm, eccentric nucleolus), frequent necrosis, microcalcifications [3, 38, 39]. Most pleomorphic LN lesions are type 3 LN. Lobular neoplasia has no radiological or clinical manifestations; it is usually 
discovered fortuitously in breast tissue readily biopsied for microcalcifications. ALH is classified as a moderate-risk lesion (relative risk of 4 to 5) [4] with a higher risk of developing breast cancer, of ductal or lobular histology, in the breast in which ALH was diagnosed [40]. LCIS is classified as a high-risk lesion (relative risk of 8 to 10) [4] with an identical risk in both breasts [41]. The mean age at diagnosis is 46 years [42]. The incidence of pure LN was approximately $1.6 \%$ of surgical breast biopsies in 1985 [1] and approximately $7.8 \%$ in 2007 [16]. The clinical and biological significance of $\mathrm{LN}$ remains subject to controversy. Immunophenotyping and cytogenetic studies demonstrate the lesional similarities with concomitant invasive carcinoma (high expression of oestrogen and progesterone receptors, low Ki-67 and well-differentiated cytokeratin profile (CK5- and CK18+)), and these findings lead some to consider LN as a precursor of invasion [43]. However, epidemiological cohort follow-up studies show that the natural history of the lesion does not necessarily lead to invasion $[16,44,45]$ : 7 cases of IC were observed following median follow-up of 160 months of 139 patients with pure LN on an excision specimen [16]. Therefore, the current consensus is to consider classic LN a risk marker [3] for breast cancer rather than a precursor of invasion. As regards the pleomorphic form of LN, epidemiological studies are lacking, but in view of the strong association with invasive lobular carcinoma, this lesion is classified as a precursor of invasion $[3,38,39]$.

To summarise, the immunohistochemistry profiles of these three lesions are similar and one could be inclined to classify them as precursors of invasion; however epidemiological followup studies have shown that the natural history of these lesions does not lead to invasion, so the current consensus is to classify them as only risk markers for breast cancer for management purposes (with the exception of pleomorphic LN) (Table 1).

\section{2 - Diagnosis of atypical hyperplasia after percutaneous sampling}


The clinical and biological significance of $\mathrm{AH}$ remains subject to debate: it is variously considered a risk marker for breast cancer or a precursor of invasion. This distinction comes to the fore when $\mathrm{AH}$ is discovered on percutaneous breast biopsy. If $\mathrm{AH}$ is a risk marker, follow-up surgical excision does not present any therapeutic benefits and one must develop a primary prevention strategy in this population at risk of breast cancer. On the other hand, if $\mathrm{AH}$ is a precursor of invasion, follow-up surgical excision is mandated for secondary prevention of breast cancer, with resection in sano. Moreover, radiological techniques for breast biopsies yield a certain number of false negatives, hence a risk of missing malignant lesions. So even if $\mathrm{AH}$ is a risk marker for cancer, its identification on percutaneous biopsy may require follow-up diagnostic surgery. Techniques for radiologically guided breast sampling are continually evolving: the quantity of tissue ranges from $17 \mathrm{mg}$ with an automated gun with $14 \mathrm{G}$ needle to $110 \mathrm{~g}$ for an aspiration system with a $10 \mathrm{G}$ probe (Vacora ${ }^{\circledR}$ system) $[46,47]$. The increase in the breast volume obtained under radiological guidance is associated with a concomitant increase in the specificity of the sample and reduces the number of false negatives. In the long term, improvement in the diagnostic sensitivity of radiological techniques will reduce the indications for follow-up surgical excision. However, the size of the needles used, the use or not of an aspiration system and the number of samples taken remain at the discretion of the radiologist (6 to 27 cores in the literature [46]). The sampling technique for a given radiological signal is not standardised. All these difficulties prevent a consensus from being reached for secondary lumpectomy after diagnosis of pure AH on percutaneous biopsy.

3.2.1 - Pure FEA on percutaneous breast biopsy. Villa et al. analysed 121 cases of FEA diagnosed on macrobiopsy ( $9 \mathrm{G}$ for 57 cases and $11 \mathrm{G}$ for 64 cases) who then underwent excision surgery. The underestimation rate of malignancy was 5.8\% (7/121) without a significant difference between the two types of macrobiopsy. However, the underestimation 
rates were $0(0 / 85)$ in the absence of residual microcalcifications post-macrobiopsy versus $19.4 \%(7 / 36)$ when microcalcifications persisted [48].

Ceugnart et al. reported an underestimation rate of $6 \%(3 / 52)$ from a retrospective series of 52 cases of FEA diagnosed on macrobiopsy $(11-8 \mathrm{G})$ who then underwent excision surgery [49]. The underestimation rates reported for FEA diagnosed on macrobiopsy $(\leq 11 \mathrm{G})$ varied from 0 to 20\%: $0(0 / 33$ and 0/24) for Piubello et al. [50] and de Mascarel et al. [2]; 3.2\% (3/95) for Uzoaru et al. [51]; 8.4\% (2/24) for Sohn et al. [52]; 14\% (4/28) for Solorzano et al. [53]; 20\% (3/15) for Ingegnoli et al. [54]. In cases of FEA diagnosed on microbiopsy, Khoumais et al. found an underestimation rate of $10 \%(10 / 94)$ and Kunju et al. found a rate of $21 \%(3 / 14)[19$, $55]$.

As current recommendations are evolving to fewer (if not no) excisions for FEA found on percutaneous biopsy (in the absence of radiologic indications for excision).

3.2.2. - Pure ADH on percutaneous breast biopsy. With regard to pure ADH identified on percutaneous biopsy, there have been many series evaluating the underestimation rate, which varied according to the technique (size of needles, aspiration system). Colombo et al. conducted a literature review: in 16 studies with 1929 cases of $\mathrm{ADH}$ [56], the underestimation rate varied from 13 to $21 \%$ in studies that exclusively or mostly included macrobiopsies (9$11 \mathrm{G})$ and 34 to $65 \%$ in studies with microbiopsy only (14 G) [56-71].

In the literature, the most common predictors of underestimation of malignant lesions (in situ or invasive) after identification of $\mathrm{ADH}$ are [56-59, 61-72]:

Microbiopsy (14 G) versus macrobiopsy (9-11 G)

Mammography ACR 4/5 versus 3, architectural distortion

Lesion with clinical symptoms, mass, visible on ultrasound

Initial radiological size $>15 \mathrm{~mm}$ 
Persistence of radiological signal post-biopsy (residual calcifications)

Multiple foci $\geq 3$

Marked cytonuclear atypia

Less well trained pathologist

In the series of Travade et al., half of the ADH patients (31/62) were not operated upon but monitored mammographically (1 patient lost to follow-up). In the group of women who did not undergo surgery and in whom macrobiopsy led to disappearance of the microcalcification focus (mean size of microcalcification foci: $6 \mathrm{~mm}(2-10 \mathrm{~mm})$ ), no cancer was found during a median follow-up of 35.5 months (range: 22-62 months) [73].

Forgeard et al. [74] proposed a decision-making algorithm based on recursive partitioning, with no surgery if:

the microcalcification focus measures less than $6 \mathrm{~mm}$ and macrobiopsy leads to complete disappearance of the microcalcification focus

$\square$ the microcalcification focus measures less than $6 \mathrm{~mm}$ but with persistence of microcalcifications or if the focus measures between 6 and $21 \mathrm{~mm}$ (with or without residual microcalcifications) and there is a maximum of 2 foci of $\mathrm{ADH}$.

Uzan et al. developed a continuous predictor based on a logistic regression model (i.e. a nomogram) based on 3 factors: age, disappearance of radiological lesions after macrobiopsy and size of microcalcification focus $(<$ or $>16 \mathrm{~mm})$ [75].

3.2.3. - Pure LN (ALH and LCIS) on percutaneous breast biopsy. In a cohort study involving 184 cases of ALH or LCIS diagnosed on radioguided breast biopsy, Shah-Khan et al. reported underestimation rates of malignancy (in situ or invasive) as determined by surgical excision [76]. Among the 184 cases, 147 (79.9\%) were ALH and 37 (20.1\%) were LCIS. Follow-up surgical excision was performed in 101 cases (54.9\%): 81/147 ALH and 20/37 LCIS (surgery group). The surveillance group contained the remaining 83 cases (66/147 ALH and 17/37 
LCIS) for which 65 cases with follow-up data enabled an analysis of data with median follow-up of 53 months (6-135 months). The breast biopsy was a macrobiopsy (9-11 G) in 143 cases $(74 / 101(73 \%)$ from the surgery group and 69/83 (83\%) from the surveillance group) and a microbiopsy ( $14 \mathrm{G}$ to $18 \mathrm{G})$ in 41 cases. The underestimation rates were $1.2 \%$ $(1 / 81)$ for ALH and 5\% (1/20) for LCIS $(p=0.36)$. In the surveillance group $(n=65)$, an ipsilateral cancer was observed in $1 / 51(2 \%)$ cases of ALH and 3/14 (21\%) cases of LCIS $(\mathrm{p}=0.04)$. In the surgery group, an ipsilateral cancer was observed during follow-up (median follow-up of 47.9 months (6-212 months)) in 1/61 (1.6\%) cases of ALH and in no cases of LCIS $(p=0.6)$. A contralateral cancer was diagnosed in $3 / 112(2.7 \%)$ cases of ALH and in $1 / 26(3.8 \%)$ cases of LCIS ( $p=0.6)$ [76]. Muray et al. reported similar findings [77]. ShahKhan et al. and Muray et al. concluded that surgery not be systematically performed in cases with histology-radiology concordance.

In the series by Zhao et al. involving 237 cases (163 ALH and 74 LCIS), the underestimation rate, determined by presence of a malignant lesion (in situ or invasive) on follow-up surgical excision, was 3.1\% (5/163) for ALH cases and 8.1\% (6/74) for LCIS cases. A macrobiopsy (9 G) had been performed in $98 \%$ of cases [78].

In cases of ALH or classic LCIS, the risk is higher in the presence of a limited biopsy (microbiopsy $14 \mathrm{G}$ yersus macrobiopsy $11-8 \mathrm{G}$ ) or lesions greater than $20 \mathrm{~mm}$ or classified BIRADS (ACR) $4 / 5$ on initial imaging and a high number of foci $(>4)$ - although the last parameter is difficult to analyse histologically. The underestimation risk seems low $(<3-5 \%)$ in the recent series with cases of ALH or classic LCIS found on macrobiopsy with verification of good histology-radiology concordance [76, 77, 79-82]. If these different criteria are met, particularly histology-radiology concordance, close surveillance without surgery may be sufficient [30-35]. 
As current recommendations are evolving to fewer (if not no) excisions for classic LN found on percutaneous biopsy (in the absence of radiologic indications for excision). Conversely, non-classic LCIS (i.e. pleomorphic LCIS, LCIS with necrosis and, for some authors, florid LCIS) carries a high risk of malignant lesion and represents a formal indication for surgical excision $[56,83,84]$.

\section{3. - Specificity of breast excision surgery: surgical excision for non-palpable lesions}

There are no specific recommendations concerning the excision technique for non-palpable AH lesions found on percutaneous biopsy. This surgery requires preoperative localisation. There are several localisation methods, the classic one being placement of a metal marker under radiological guidance before the procedure. Given that the majority of patients are young women (mean age at diagnosis of 46 years) undergoing surgery for benign lesions, cosmetic considerations are important and indirect incisions are preferred. Furthermore, given the non-negligible rate of DCIS and invasive carcinoma on definitive histology $(0 \%$ to $46 \%$ depending on $\mathrm{AH}$ ), the surgical excision must remove the part of the breast from the pectoral muscle to the cutaneous plane centred on the marker. In cases of invasive carcinoma or DCIS, histological analysis of the excision specimen will render the margin status interpretable. For the same reason, the specimen must be orientated by the surgeon and radiologist in order to ascertain that the radiological signal is completely removed and at a distance from the edges of the specimen. Intraoperative frozen section analysis of the surgical specimen is not recommended (no target nodule for the pathologist, difficult histological analysis with

borderline lesions, risk of not leaving any tissue for the permanent section). As a result of these constraints, in cases of invasive carcinoma or ductal carcinoma in situ, the diagnosis is known post-operatively. The patient must therefore be informed of the possibility of a second procedure for excision margins and if necessary for lymph node analysis. The axillary lymph node analysis presents the problem of performing sentinel lymph node biopsy on a previously 
operated breast. This is not recommended but feasibility studies are currently underway in France after studies demonstrated that there was no increase in the rate of false negatives with sentinel lymph node biopsy performed on a recently operated breast [85].

\subsection{Management of surgical margins in presence of pure atypical hyperplasia}

3.4.1. - Pure flat epithelial atypia in a surgical specimen. FEA has only been designated recently and there are no data on the effect of margins positive for FEA in a breast surgical specimen. In view of the low malignant potential of this lesion in the 3 cohort follow-up studies $[2,13,26]$, the authors do not recommend re-excision [11].

3.4.2. - Pure atypical ductal hyperplasia in a surgical specimen. There are few studies evaluating the effect of positive margins in a surgical specimen with pure ADH. One study indicated that margins positive for ADH had no effect on the development of invasion [86]: this series had a small number of patients and short follow-up. Arora et al. consider that ADH at margins is a marker of an adjacent malignant lesion justifying further surgery [87]: in this study, underestimation could be interpreted as a false negative of the surgery, which did not remove the target radiological lesion. Given the expected low malignant potential of ADH following surgical excision (3\% after a follow-up of 160 months [16]), further surgery for margins positive for $\mathrm{ADH}$ in a surgical specimen is not recommended [3].

3.4.3. - Pure lobular neoplasia in a surgical specimen. LN lesions are often multifocal and bilateral [42] and negative margins vis-à-vis this lesion do not guarantee that all LN lesions have been removed from the ipsilateral (and also contralateral) breast. Classic LCIS is considered a risk marker for breast cancer and it is recommended to not perform further surgery for margins positive for classic LCIS in a surgical specimen [3]. Pleomorphic LCIS must be approached distinctly, specifically as a precursor lesion of breast cancer for which excision with negative margins is recommended [3, 38, 45]. Some teams even treat it as DCIS 
with radiotherapy in case of conservative treatment $[38,45]$. However, the benefits of such radiotherapy have never been studied for pleomorphic LCIS.

In conclusion, in cases of pure $\mathrm{AH}$ identified on surgical breast biopsy, the consensus is to not perform further surgery in cases of positive margins for the lesion considered (with the exception of pleomorphic LCIS).

\section{5. - Management of surgical margins in presence of atypical hyperplasia and invasive} cancer

3.5.1 - Flat epithelial atypia with DCIS or IC in a surgical specimen. There are no series evaluating the margin status vis-à-vis this lesion in association with DCIS or IC, but given that flat epithelial atypia has low potential for recurrence or progression to invasion, the margins for this lesion may be disregarded [12].

3.5.2 - Atypical ductal hyperplasia with DCIS or IC in a surgical specimen. There are few studies evaluating the effect of margins positive for ADH in surgical specimens with ADH in association with DCIS or IC. Arora et al. consider that the presence of ADH at or less than $1 \mathrm{~mm}$ from margins is a marker of an adjacent malignant lesion justifying re-excision [87]; but in this study, rather than fear of missing a malignant lesion, attention must be drawn to the incomplete surgery that did not excise the totality of the signal. In view of the low expected potential for development of ADH after surgical excision (3\% for follow-up of 160 months [16]), re-excision for margins positive for $\mathrm{ADH}$ on a surgical specimen is not recommended [3].

3.5.3 - Lobular neoplasia with DCIS or IC in a surgical specimen. Studies involving invasive carcinomas in association with lobular neoplasia lesions show that margin status vis-à-vis lobular neoplasia does not affect recurrence-free survival or the rate of cancer recurrence [8890]. Re-excision for margins positive for classic LN in a surgical specimen is not 
recommended [3]. As regards pleomorphic LCIS, margins negative for the pleomorphic LCIS component are essential for achieving local control of the disease [38], because this lesion is considered a precursor, a hypothesis verified for the specific case of invasive lesions surrounded by pleomorphic LCIS.

In conclusion, in cases of identification of $\mathrm{AH}$ in association with LCIS or IC on a surgical specimen, the consensus is to not perform further surgery in cases of positive margins for the AH lesion (with the exception of pleomorphic LCIS).

\section{6. - Role of hormone replacement therapy in patients with atypical hyperplasia of the} breast

$\mathrm{AH}$ is at the least a risk marker for breast cancer: its presence places the patient at a higher risk of breast cancer than the general population [4]. Hormone replacement therapy (HRT) increases the relative risk of breast cancer in non-selected populations, as has been shown in an American intervention study [91] and British [92] and French [93] observational studies.

The effect of HRT or oestrogen-only therapy in a normal breast is to increase the risk of development of a benign proliferative lesion without [94-97] or with atypia [97] (Table 5). The effect of HRT in a population of patients with proliferative lesions of the breast without atypia is also to increase the risk of development of AH [98] (Table 5). It is difficult to evaluate the extent to which taking HRT induces a potential additional risk of developing breast cancer in the population with $\mathrm{AH}$, owing to the low incidence of $\mathrm{AH}$ lesions and the paucity of studies addressing this issue.

The results of published studies are contradictory, but they all have confounding factors [99104]: the studies were published over a period spanning 20 years during which terminology as well as pathological evaluation of breast lesions evolved considerably; even the nature of the hormonal treatment, in terms of the molecules used and the duration of treatment and the 
daily dosage, are not homogeneous between series or within the same series, thereby affecting the development or not of an increased risk of breast cancer; the follow-up period of these studies is variable and possibly insufficient for detecting a late effect of the prescribed therapy on $\mathrm{AH}$ if one considers the developmental sequence with hyperplastic lesions becoming atypical hyperplastic lesions. The classic biases of retrospective studies are also apparent, particularly the "healthy patient" bias in which the treatments are offered to patients with the fewest breast risk factors and better able to tolerate the treatments. All the publications agree that HRT induces the development of benign proliferative pathologies of the breast with or without atypia but they disagree over whether HRT increases the risk of progression to the next stage in the carcinogenesis model, namely that of atypical hyperplasia. All in all, the majority of authors remain reticent about the use of HRT in this population that is already at higher risk of breast cancer: Gayet et al. notably conclude that discovery of AH in a patient on HRT should prompt consideration of whether to continue HRT [98].

Two major prevention trials (NSABP-PI and IBIS-I) have included women with atypical hyperplasia as a specific entry riterion making them eligible to join these placebo controlled trials of tamoxifen for breast cancer prevention [9, 105]. Both trials have reported on the effect of tamoxifen in women with AH or LCIS. In the P1 trial, a larger effect of tamoxifen was seen for women with $\mathrm{AH}(86 \%$ reduction) compared to those in the trial overall $(49 \%$ reduction) [9]. In the same way, two other trials have evaluated aromatase inhibitors for breast cancer prevention [106, 107], and both have explicitly reported on their effect among women with AH. A reduction in breast cancer incidence of 39\% was found with exemestane when compared to placebo. Thus, the role of chemoprevention for reducing the risk of breast cancer in patients with $\mathrm{AH}$ was evidenced. Nevertheless, a meta-analysis of five studies found generally lower acceptance rates of chemoprevention $(14,8 \%$ on average) [108]. A more recent study of high-risk women also found modest acceptance of chemoprevention $(10,6 \%)$ 
[109]. Thus, even though the benefit/risk ratios for chemopreventive agents are favourable for many women, studies show that these agents are infrequently prescribed and used [110]. Further research is needed to better understand the barriers preventing wider use of chemoprevention.

\section{4. - Conclusion}

Atypical hyperplasia of the breast is a field in constant flux, in terms of nosology and its role in carcinogenesis pathways. Immunohistochemical and cytogenetic studies hold that $\mathrm{AH}$ lesions are precursors of invasive breast cancers, but epidemiological cohort studies have demonstrated a relatively low rate of invasion [16] such that these lesions (with the exception of pleomorphic LN) should rather be considered a risk marker for breast cancer for management purposes. Discovery of an $\mathrm{AH}$ lesion on percutaneous breast biopsy is an almost systematic indication for surgical excision, regardless of the size of the needle used and the number of samples obtained. This follow-up surgical excision requires surgical rigour and close cooperation with the radiologist. In a breast surgical specimen, margins positive for an $\mathrm{AH}$ lesion do not mandate a further surgical procedure (with the exception of pleomorphic LN) because local control of the disease does not seem to be impaired. Finally, hormone replacement therapy in patients with $\mathrm{AH}$ must be limited to those who absolutely need it and who have received necessary information. The role of chemoprevention for patients with $\mathrm{AH}$ is still under debate.

5. Expert commentary: For atypical ductal hyperplasia and lobular carcinoma in situ, surgical excision is commonly recommended, but for atypical lobular hyperplasia and flat epithelial with atypia, close follow-up without surgery could be recommended. Expectant management is feasible after multidisciplinary consensus.

6. Five-year view: Prospective studies are required to determine which women with breast 
atypical epithelial hyperplasia on radiological sampling could be spared surgery. Nevertheless, current recommendations are evolving to fewer (if not no) excisions for flat epithelial with atypia and classic lobular neoplasia found on percutaneous biopsy (in the absence of radiologic indications for excision). Although the benefit/risk ratio of chemopreventive agents is favourable for many women, studies show that these agents are infrequently prescribed and used. The role of chemoprevention needs to be determined for women with AEH.

\section{Key issues:}

- Atypical ductal hyperplasia (ADH), flat epithelial atypia (FEA), atypical lobular hyperplasia (ALH) and lobular carcinoma in situ (LCIS) are proliferations of monomorphic epithelial cells in the terminal ductal lobular unit as defined by the histological criteria of the 2012 WHO classification.

- For ADH diagnosed on percutaneous biopsy, the rate of underestimation (i.e. missing invasive breast carcinoma or ductal carcinoma in situ) varies from 13 to $21 \%$ (LE3). Predictors of underestimation are $14 \mathrm{G}$ instead of $9-11 \mathrm{G}$ biopsy, BI-RADS category 4-5 versus 3, architectural distortion, clinically symptomatic lesion, mass, ultrasound signal, radiological size $>15 \mathrm{~mm}$, persistence of post-biopsy radiological signal (residual calcifications), multiple foci $\geq 3$, marked cytonuclear atypia and less experienced pathologist.

- For FEA diagnosis on percutaneous biopsy, the underestimation rate (i.e. missing invasive breast carcinoma or ductal carcinoma in situ) is between 0 and $20 \%$ (LE4). In cases of ALH or LCIS diagnosis on vacuum-assisted core needle biopsy, the underestimation rate of malignancy varies between $3 \%$ and $17 \%$, mainly depending on histology-radiology concordance. In cases of nonclassic LCIS, the underestimation rate is around $50 \%$.

- For ADH, ALH, LCIS, FEA: surgical excision is recommended, but expectant management is feasible following multidisciplinary discussion.

- For LCIS: the relative risk of cancer is 8 and specific follow-up is recommended. 
- For ADH and ALH: the relative risk of cancer is 4 and specific follow-up is recommended.

- For FEA: the relative risk of cancer is less than 2.

\section{Funding}

This paper was not funded.

\section{Declaration of interest}

The authors have no relevant affiliations or financial involvement with any organization or entity with a financial interest in or financial conflict with the subject matter or materials discussed in the manuscript. This includes employment, consultancies, honoraria, stock ownership or options, expert testimony, grants or patents received or pending, or royalties. The authors would like to thank Tracey Westcott for editing the draft.

\section{References}

[1] Page DL, Dupont WD, Rogers LW, Rados MS. Atypical hyperplastic lesions of the female breast. A long-term follow-up study. Cancer. 1985;55:2698-708.

[2] de Mascarel I, MacGrogan G, Mathoulin-Pelissier S, Vincent-Salomon A, Soubeyran I, Picot V, et al. Epithelial atypia in biopsies performed for microcalcifications. practical considerations about 2,833 serially sectioned surgical biopsies with a long follow-up. Virchows Arch. 2007;451:1-10.

[3] Tavassoli F, Millis R, Boecker W, Lakhani S, . World Health Organization Classification of Tumours. Pathology and Genetics of Tumours of the Breast and Female Genital Organs. 2003:60-76.

[4] Fitzgibbons PL, Henson DE, Hutter RV. Benign breast changes and the risk for subsequent breast cancer: an update of the 1985 consensus statement. Cancer Committee of the College of American Pathologists. Arch Pathol Lab Med. 1998;122:1053-5.

[5] Bratthauer GL, Tavassoli FA. Lobular intraepithelial neoplasia: previously unexplored aspects assessed in 775 cases and their clinical implications. Virchows Arch. 2002;440:134-8.

[6] Reis-Filho JS, Simpson PT, Jones C, Steele D, Mackay A, Iravani M, et al. Pleomorphic lobular carcinoma of the breast: role of comprehensive molecular pathology in characterization of an entity. $\mathrm{J}$ Pathol. 2005;207:1-13.

[7] Moinfar F, Man YG, Bratthauer GL, Ratschek M, Tavassoli FA. Genetic abnormalities in mammary ductal intraepithelial neoplasia-flat type ("clinging ductal carcinoma in situ"): a simulator of normal mammary epithelium. Cancer. 2000;88:2072-81. 
[8] Simpson PT, Gale T, Reis-Filho JS, Jones C, Parry S, Sloane JP, et al. Columnar cell lesions of the breast: the missing link in breast cancer progression? A morphological and molecular analysis. Am J Surg Pathol. 2005;29:734-46.

[9] Fisher B, Costantino JP, Wickerham DL, Redmond CK, Kavanah M, Cronin WM, et al. Tamoxifen for prevention of breast cancer: report of the National Surgical Adjuvant Breast and Bowel Project P-1 Study. J Natl Cancer Inst. 1998;90:1371-88.

[10] Fisher B, Costantino JP, Wickerham DL, Cecchini RS, Cronin WM, Robidoux A, et al. Tamoxifen for the prevention of breast cancer: current status of the National Surgical Adjuvant Breast and Bowel Project P-1 study. J Natl Cancer Inst. 2005;97:1652-62.

[11] Schnitt SJ. The diagnosis and management of pre-invasive breast disease: flat epithelial atypiaclassification, pathologic features and clinical significance. Breast Cancer Res. 2003;5:263-8.

[12] Schnitt SJ, Vincent-Salomon A. Columnar cell lesions of the breast. Adv Anat Pathol. 2003;10:113-24.

[13] Eusebi V, Feudale E, Foschini MP, Micheli A, Conti A, Riva C, et al. Long-term follow-up of in situ carcinoma of the breast. Semin Diagn Pathol. 1994;11:223-35.

[14] Pinder SE, Reis-Filho JS. Non-operative breast pathology: columnar cell lesions. J Clin Pathol. 2007;60:1307-12.

[15] Elston CW, Sloane JP, Amendoeira I, Apostolikas N, Bellocq JP, Bianchi S, et al. Causes of inconsistency in diagnosing and classifying intraductal proliferations of the breast. European Commission Working Group on Breast Screening Pathology. Eur J Cancer. 2000;36:1769-72.

[16] de Mascarel I, MacGrogan G. Prise en charge des atypies épithéliales du sein. Ann Pathol. 2007;27:182-94.

[17] Collins LC, Achacoso NA, Nekhlyudov L, Fletcher SW, Haque R, Quesenberry CP, Jr., et al. Clinical and pathologic features of ductal carcinoma in situ associated with the presence of flat epithelial atypia: an analysis of 543 patients. Mod Pathol. 2007;20:1149-55.

[18] Fraser JL, Raza S, Chorny K, Connolly JL, Schnitt SJ. Columnar alteration with prominent apical snouts and secretions: a spectrum of changes frequently present in breast biopsies performed for microcalcifications. Am J Surg Pathol. 1998;22:1521-7.

[19] Kunju LP, Kleer CG. Significance of flat epithelial atypia on mammotome core needle biopsy: Should it be excised? Hum Pathol. 2007;38:35-41.

[20] Oyama T, Iijima K, Takei H, Horiguchi J, Iino Y, Nakajima T, et al. Atypical cystic lobule of the breast: an early stage of low-grade ductal carcinoma in-situ. Breast Cancer. 2000;7:326-31.

[21] Simpson PT, Reis-Filho JS, Gale T, Lakhani SR. Molecular evolution of breast cancer. J Pathol. 2005;205:248-54.

[22] Goldstein NS, O'Malley BA. Cancerization of small ectatic ducts of the breast by ductal carcinoma in situ cells with apocrine snouts: a lesion associated with tubular carcinoma. Am J Clin Pathol. 1997;107:561-6.

[23] Dessauvagie BF, Zhao W, Heel-Miller KA, Harvey J, Bentel JM. Characterization of columnar cell lesions of the breast: immunophenotypic analysis of columnar alteration of lobules with prominent apical snouts and secretions. Hum Pathol. 2007;38:284-92.

[24] Abdel-Fatah TM, Powe DG, Hodi Z, Reis-Filho JS, Lee AH, Ellis IO. Morphologic and molecular evolutionary pathways of low nuclear grade invasive breast cancers and their putative precursor lesions: further evidence to support the concept of low nuclear grade breast neoplasia family. Am J Surg Pathol. 2008;32:513-23.

[25] Dabbs DJ, Carter G, Fudge M, Peng Y, Swalsky P, Finkelstein S. Molecular alterations in columnar cell lesions of the breast. Mod Pathol. 2006;19:344-9.

[26] Bijker N, Peterse JL, Duchateau L, Julien JP, Fentiman IS, Duval C, et al. Risk factors for recurrence and metastasis after breast-conserving therapy for ductal carcinoma-in-situ: analysis of European Organization for Research and Treatment of Cancer Trial 10853. J Clin Oncol. 2001;19:2263-71.

[27] Boulos FI, Dupont WD, Simpson JF, Schuyler PA, Sanders ME, Freudenthal ME, et al. Histologic associations and long-term cancer risk in columnar cell lesions of the breast: a retrospective cohort and a nested case-control study. Cancer. 2008;113:2415-21.

[28] Said SM, Visscher DW, Nassar A, Frank RD, Vierkant RA, Frost MH, et al. Flat epithelial atypia and risk of breast cancer: A Mayo cohort study. Cancer. 2015;121:1548-55. 
[29] Aroner SA, Collins LC, Schnitt SJ, Connolly JL, Colditz GA, Tamimi RM. Columnar cell lesions and subsequent breast cancer risk: a nested case-control study. Breast Cancer Res. 2010;12:R61.

[30] Boulos FI, Dupont WD, Schuyler PA, Sanders ME, Page DL, Fedda FA, et al. Clinicopathologic characteristics of carcinomas that develop after a biopsy containing columnar cell lesions: evidence against a precursor role. Cancer. 2012;118:2372-7.

[31] Page DL, Rogers LW. Combined histologic and cytologic criteria for the diagnosis of mammary atypical ductal hyperplasia. Hum Pathol. 1992;23:1095-7.

[32] Hartmann LC, Sellers TA, Frost MH, Lingle WL, Degnim AC, Ghosh K, et al. Benign breast disease and the risk of breast cancer. N Engl J Med. 2005;353:229-37.

[33] Degnim AC, Visscher DW, Berman HK, Frost MH, Sellers TA, Vierkant RA, et al. Stratification of breast cancer risk in women with atypia: a Mayo cohort study. J Clin Oncol. 2007;25:2671-7.

[34] Reis-Filho JS, Lakhani SR. The diagnosis and management of pre-invasive breast disease: genetic alterations in pre-invasive lesions. Breast Cancer Res. 2003;5:313-9.

[35] Gong G, DeVries S, Chew KL, Cha I, Ljung BM, Waldman FM. Genetic changes in paired atypical and usual ductal hyperplasia of the breast by comparative genomic hybridization. Clin Cancer Res. 2001;7:2410-4.

[36] Page DL, Kidd TE, Jr., Dupont WD, Simpson JF, Rogers LW. Lobular neoplasia of the breast: higher risk for subsequent invasive cancer predicted by more extensive disease. Hum Pathol. 1991;22:1232-9.

[37] Rosen PP, Kosloff C, Lieberman PH, Adair F, Braun DW, Jr. Lobular carcinoma in situ of the breast. Detailed analysis of 99 patients with average follow-up of 24 years. Am J Surg Pathol. 1978;2:225-51.

[38] Sneige N, Wang J, Baker BA, Krishnamurthy S, Middleton LP, Clinical, histopathologic, and biologic features of pleomorphic lobular (ductal-lobular) carcinoma in situ of the breast: a report of 24 cases. Mod Pathol. 2002;15:1044-50.

[39] Georgian-Smith D, Lawton TJ. Calcifications of lobular carcinoma in situ of the breast: radiologic-pathologic correlation. AJR Am J Roentgenol. 2001;176:1255-9.

[40] Page DL, Schuyler PA, Dupont WD, Jensen RA, Plummer WD, Jr., Simpson JF. Atypical lobular hyperplasia as a unilateral predictor of breast cancer risk: a retrospective cohort study. Lancet. 2003;361:125-9.

[41] Li CI, Anderson BO, Daling JR, Moe RE. Trends in incidence rates of invasive lobular and ductal breast carcinoma. Jama. 2003;289:1421-4.

[42] Haagensen CD, Lane N, Lattes R, Bodian C. Lobular neoplasia (so-called lobular carcinoma in situ) of the breast. Cancer. 1978:42:737-69.

[43] Shelley Hwang E, Nyante SJ, Yi Chen Y, Moore D, DeVries S, Korkola JE, et al. Clonality of lobular carcinoma in situ and synchronous invasive lobular carcinoma. Cancer. 2004;100:2562-72.

[44] Chuba PJ, Hamre MR, Yap J, Severson RK, Lucas D, Shamsa F, et al. Bilateral risk for subsequent breast cancer after lobular carcinoma-in-situ: analysis of surveillance, epidemiology, and end results data. J Clin Oncol. 2005;23:5534-41.

[45] Fisher ER, Land SR, Fisher B, Mamounas E, Gilarski L, Wolmark N. Pathologic findings from the National Surgical Adjuvant Breast and Bowel Project: twelve-year observations concerning lobular carcinoma in situ. Cancer. 2004;100:238-44.

[46] Burbank F, Parker SH, Fogarty TJ. Stereotactic breast biopsy: improved tissue harvesting with the Mammotome. Am Surg. 1996;62:738-44.

[47] Berg WA, Krebs TL, Campassi C, Magder LS, Sun CC. Evaluation of 14- and 11-gauge directional, vacuum-assisted biopsy probes and 14-gauge biopsy guns in a breast parenchymal model. Radiology. 1997;205:203-8.

[48] Villa A, Chiesa F, Massa T, Friedman D, Canavese G, Baccini P, et al. Flat epithelial atypia: comparison between 9-gauge and 11-gauge devices. Clin Breast Cancer. 2013;13:450-4.

[49] Ceugnart L, Doualliez V, Chauvet MP, Robin YM, Bachelle F, Chaveron C, et al. Pure flat epithelial atypia: is there a place for routine surgery? Diagn Interv Imaging. 2013;94:861-9.

[50] Piubello Q, Parisi A, Eccher A, Barbazeni G, Franchini Z, Iannucci A. Flat epithelial atypia on core needle biopsy: which is the right management? Am J Surg Pathol. 2009;33:1078-84. 
[51] Uzoaru I, Morgan BR, Liu ZG, Bellafiore FJ, Gaudier FS, Lo JV, et al. Flat epithelial atypia with and without atypical ductal hyperplasia: to re-excise or not. Results of a 5-year prospective study. Virchows Arch. 2012;461:419-23.

[52] Sohn V, Porta R, Brown T. Flat epithelial atypia of the breast on core needle biopsy: an indication for surgical excision. Mil Med. 2011;176:1347-50.

[53] Solorzano S, Mesurolle B, Omeroglu A, El Khoury M, Kao E, Aldis A, et al. Flat epithelial atypia of the breast: pathological-radiological correlation. AJR Am J Roentgenol. 2011;197:740-6.

[54] Ingegnoli A, d'Aloia C, Frattaruolo A, Pallavera L, Martella E, Crisi G, et al. Flat epithelial atypia and atypical ductal hyperplasia: carcinoma underestimation rate. Breast J. 2010;16:55-9.

[55] Khoumais NA, Scaranelo AM, Moshonov H, Kulkarni SR, Miller N, McCready DR, et al. Incidence of breast cancer in patients with pure flat epithelial atypia diagnosed at core-needle biopsy of the breast. Ann Surg Oncol. 2013;20:133-8.

[56] Colombo PE, Vincent-Salomon A, Chateau MC, Mourregot A, Gutowski M, Laffargue G, et al. [Breast surgeon role in the management of high-risk breast lesions]. Bull Cancer. 2014;101.718-29.

[57] Gumus H, Mills P, Gumus M, Fish D, Jones S, Jones P, et al. Factors that impaet the upgrading of atypical ductal hyperplasia. Diagn Interv Radiol. 2013;19:91-6.

[58] McGhan LJ, Pockaj BA, Wasif N, Giurescu ME, McCullough AE, Gray RJ. Atypical ductal hyperplasia on core biopsy: an automatic trigger for excisional biopsy? Ann Surg Oncol. 2012;19:3264-9.

[59] Kim J, Han W, Go EY, Moon HG, Ahn SK, Shin HC, et al. Validation of a scoring system for predicting malignancy in patients diagnosed with atypical ductal hyperplasia using an ultrasoundguided core needle biopsy. J Breast Cancer. 2012;15:407-11.

[60] Bendifallah S, Defert S, Chabbert-Buffet N, Maurin N, Chopier J, Antoine M, et al. Scoring to predict the possibility of upgrades to malignancy in atypical ductal hyperplasia diagnosed by an 11gauge vacuum-assisted biopsy device: an external validation study. Eur J Cancer. 2012;48:30-6.

[61] Hong ZJ, Chu CH, Fan HL, Hsu HM, Chen CJ, Chan DC, et al. Factors predictive of breast cancer in open biopsy in cases with atypical ductal hyperplasia diagnosed by ultrasound-guided core needle biopsy. Eur J Surg Oncol. 2011;37:758-64.

[62] Villa A, Tagliafico A, Chiesa F, Chiaramondia M, Friedman D, Calabrese M. Atypical ductal hyperplasia diagnosed at 11-gauge vacuum-assisted breast biopsy performed on suspicious clustered microcalcifications: could patients without residual microcalcifications be managed conservatively? AJR Am J Roentgenol. 2011;197:1012-8.

[63] Wagoner MJ, Laronga C, Acs G. Extent and histologic pattern of atypical ductal hyperplasia present on core needle biopsy/specimens of the breast can predict ductal carcinoma in situ in subsequent excision. Am J Clin Pathol. 2009;131:112-21.

[64] Jang M, Cho N, Moon WK, Park JS, Seong MH, Park IA. Underestimation of atypical ductal hyperplasia at sonographically guided core biopsy of the breast. AJR Am J Roentgenol. 2008; 191:1347-51.

[65] Youk JH, Kim EK, Kim MJ. Atypical ductal hyperplasia diagnosed at sonographically guided 14gauge core needle biopsy of breast mass. AJR Am J Roentgenol. 2009;192:1135-41.

[66] Deshaies I, Provencher L, Jacob S, Cote G, Robert J, Desbiens C, et al. Factors associated with upgrading to malignancy at surgery of atypical ductal hyperplasia diagnosed on core biopsy. Breast. 2011:20:50-5.

[67] Chae BJ, Lee A, Song BJ, Jung SS. Predictive factors for breast cancer in patients diagnosed atypical ductal hyperplasia at core needle biopsy. World J Surg Oncol. 2009;7:77.

[68] Ko E, Han W, Lee JW, Cho J, Kim EK, Jung SY, et al. Scoring system for predicting malignancy in patients diagnosed with atypical ductal hyperplasia at ultrasound-guided core needle biopsy. Breast Cancer Res Treat. 2008;112:189-95.

[69] Kohr JR, Eby PR, Allison KH, DeMartini WB, Gutierrez RL, Peacock S, et al. Risk of upgrade of atypical ductal hyperplasia after stereotactic breast biopsy: effects of number of foci and complete removal of calcifications. Radiology. 2010;255:723-30.

[70] Eby PR, Ochsner JE, DeMartini WB, Allison KH, Peacock S, Lehman CD. Frequency and upgrade rates of atypical ductal hyperplasia diagnosed at stereotactic vacuum-assisted breast biopsy: 9-versus 11-gauge. AJR Am J Roentgenol. 2009;192:229-34. 
[71] Nguyen CV, Albarracin CT, Whitman GJ, Lopez A, Sneige N. Atypical ductal hyperplasia in directional vacuum-assisted biopsy of breast microcalcifications: considerations for surgical excision. Ann Surg Oncol. 2011;18:752-61.

[72] Allison KH, Eby PR, Kohr J, DeMartini WB, Lehman CD. Atypical ductal hyperplasia on vacuum-assisted breast biopsy: suspicion for ductal carcinoma in situ can stratify patients at high risk for upgrade. Hum Pathol. 2011;42:41-50.

[73] Travade A, Isnard A, Bouchet F, Bagard C. [Non-palpable breast lesions and core needle biopsy with Mammotome 11G: is surgery required in patients with atypical ductal hyperplasia?]. J Radiol. 2006;87:307-10.

[74] Forgeard C, Benchaib M, Guerin N, Thiesse P, Mignotte H, Faure C, et al. Is surgical biopsy mandatory in case of atypical ductal hyperplasia on 11-gauge core needle biopsy? A retrospective study of 300 patients. Am J Surg. 2008;196:339-45.

[75] Uzan C, Mazouni C, Ferchiou M, Ciolovan L, Balleyguier C, Mathieu MC, et al A model to predict the risk of upgrade to malignancy at surgery in atypical breast lesions discovered on percutaneous biopsy specimens. Ann Surg Oncol. 2013;20:2850-7.

[76] Shah-Khan MG, Geiger XJ, Reynolds C, Jakub JW, Deperi ER, Glazebrook KN, Long-term follow-up of lobular neoplasia (atypical lobular hyperplasia/lobular carcinoma in situ) diagnosed on core needle biopsy. Ann Surg Oncol. 2012;19:3131-8.

[77] Murray MP, Luedtke C, Liberman L, Nehhozina T, Akram M, Brogi E. Classic lobular carcinoma in situ and atypical lobular hyperplasia at percutaneous breast core biopsy: outcomes of prospective excision. Cancer. 2013;119:1073-9.

[78] Zhao C, Desouki MM, Florea A, Mohammed K, Li X, Dabbs D. Pathologic findings of follow-up surgical excision for lobular neoplasia on breast core biopsy performed for calcification. Am J Clin Pathol. 2012;138:72-8.

[79] Hwang H, Barke LD, Mendelson EB, Susnik B. Atypical lobular hyperplasia and classic lobular carcinoma in situ in core biopsy specimens: routine excision is not necessary. Mod Pathol. 2008.

[80] Rendi MH, Dintzis SM, Lehman CD, Calhoun KE, Allison KH. Lobular in-situ neoplasia on breast core needle biopsy: imaging indication and pathologic extent can identify which patients require excisional biopsy. Ann Surg Oncol. 2012;19:914-21.

[81] Chaudhary S, Lawrence L, McGinty G, Kostroff K, Bhuiya T. Classic lobular neoplasia on core biopsy: a clinical and radio-pathologic correlation study with follow-up excision biopsy. Mod Pathol. 2013;26:762-71.

[82] Brem RF, Lechner MC, Jackman RJ, Rapelyea JA, Evans WP, Philpotts LE, et al. Lobular neoplasia at percutaneous breast biopsy: variables associated with carcinoma at surgical excision. AJR Am J Roentgenol. 2008;190:637-41.

[83] Shin SJ, Lal A, De Vries S, Suzuki J, Roy R, Hwang ES, et al. Florid lobular carcinoma in situ: molecular profiling and comparison to classic lobular carcinoma in situ and pleomorphic lobular carcinoma in situ. Hum Pathol. 2013;44:1998-2009.

[84] Hussain M, Cunnick GH. Management of lobular carcinoma in-situ and atypical lobular hyperplasia of the breast--a review. Eur J Surg Oncol. 2011;37:279-89.

[85] Wong SL, Edwards MJ, Chao C, Tuttle TM, Noyes RD, Carlson DJ, et al. The effect of prior breast biopsy method and concurrent definitive breast procedure on success and accuracy of sentinel lymph node biopsy. Ann Surg Oncol. 2002;9:272-7.

[86] Greene T, Tartter PI, Smith SR, Estabrook A. The significance of surgical margins for patients with atypical ductal hyperplasia. Am J Surg. 2006;192:499-501.

[87] Arora S, Menes TS, Moung C, Nagi C, Bleiweiss I, Jaffer S. Atypical ductal hyperplasia at margin of breast biopsy--is re-excision indicated? Ann Surg Oncol. 2008;15:843-7.

[88] Sasson AR, Fowble B, Hanlon AL, Torosian MH, Freedman G, Boraas M, et al. Lobular carcinoma in situ increases the risk of local recurrence in selected patients with stages I and II breast carcinoma treated with conservative surgery and radiation. Cancer. 2001;91:1862-9.

[89] Abner AL, Connolly JL, Recht A, Bornstein B, Nixon A, Hetelekidis S, et al. The relation between the presence and extent of lobular carcinoma in situ and the risk of local recurrence for patients with infiltrating carcinoma of the breast treated with conservative surgery and radiation therapy. Cancer. 2000;88:1072-7. 
[90] Ben-David MA, Kleer CG, Paramagul C, Griffith KA, Pierce LJ. Is lobular carcinoma in situ as a component of breast carcinoma a risk factor for local failure after breast-conserving therapy? Results of a matched pair analysis. Cancer. 2006;106:28-34.

[91] Rossouw JE, Anderson GL, Prentice RL, LaCroix AZ, Kooperberg C, Stefanick ML, et al. Risks and benefits of estrogen plus progestin in healthy postmenopausal women: principal results From the Women's Health Initiative randomized controlled trial. Jama. 2002;288:321-33.

[92] Beral V. Breast cancer and hormone-replacement therapy in the Million Women Study. Lancet. 2003;362:419-27.

[93] Fournier A, Berrino F, Clavel-Chapelon F. Unequal risks for breast cancer associated with different hormone replacement therapies: results from the E3N cohort study. Breast Cancer Res Treat. 2008; 107:103-11.

[94] Hofseth LJ, Raafat AM, Osuch JR, Pathak DR, Slomski CA, Haslam SZ. Hormone replacement therapy with estrogen or estrogen plus medroxyprogesterone acetate is associated with increased epithelial proliferation in the normal postmenopausal breast. J Clin Endocrinol Metab. 1999,84:455965.

[95] Rohan TE, Negassa A, Chlebowski RT, Habel L, McTiernan A, Ginsberg M, et al. Conjugated equine estrogen and risk of benign proliferative breast disease: a randomized controlled trial. J Natl Cancer Inst. 2008;100:563-71.

[96] Rohan TE, Negassa A, Chlebowski RT, Lasser NL, McTiernan A, Schenken RS, et al. Estrogen plus progestin and risk of benign proliferative breast disease. Cancer Epidemiol Biomarkers Prev. 2008; 17:2337-43.

[97] Cui Y, Page DL, Lane DS, Rohan TE. Menstrual and reproductive history, postmenopausal hormone use, and risk of benign proliferative epithelial disorders of the breast: a cohort study. Breast Cancer Res Treat. 2009;114:113-20.

[98] Gayet A, Esteve J, Seradour B, Piana L, Jacquemier J. Does hormone replacement therapy increase the frequency of breast atypical hyperplasia in postmenopausal women? Results from the Bouches du Rhone district screening campaign. Eur J Cancer. 2003;39:1738-45.

[99] Thomas DB, Persing JP, Hutchinson WB. Exogenous estrogens and other risk factors for breast cancer in women with benign breast diseases. J Natl Cancer Inst. 1982;69:1017-25.

[100] Ross RK, Paganini-Hill A, Gerkins VR, Mack TM, Pfeffer R, Arthur M, et al. A case-control study of menopausal estrogen therapy and breast cancer. Jama. 1980;243:1635-9.

[101] Brinton LA, Hoover R, Fraumeni JF, Jr. Menopausal oestrogens and breast cancer risk: an expanded case-control study. Br J Cancer. 1986;54:825-32.

[102] Dupont WD, Page DL, Rogers LW, Parl FF. Influence of exogenous estrogens, proliferative breast disease, and other variables on breast cancer risk. Cancer. 1989;63:948-57.

[103] Dupont WD, Page DL, Parl FF, Plummer WD, Jr., Schuyler PA, Kasami M, et al. Estrogen replacement therapy in women with a history of proliferative breast disease. Cancer. 1999;85:1277-83.

[104] Byrne C, Connolly JL, Colditz GA, Schnitt SJ. Biopsy confirmed benign breast disease, postmenopausal use of exogenous female hormones, and breast carcinoma risk. Cancer. 2000;89:2046-52.

[105] Cuzick J, Forbes J, Edwards R, Baum M, Cawthorn S, Coates A, et al. First results from the International Breast Cancer Intervention Study (IBIS-I): a randomised prevention trial. Lancet. 2002;360:817-24.

[106] Cuzick J, Sestak I, Forbes JF, Dowsett M, Knox J, Cawthorn S, et al. Anastrozole for prevention of breast cancer in high-risk postmenopausal women (IBIS-II): an international, double-blind, randomised placebo-controlled trial. Lancet. 2014;383:1041-8.

[107] Goss PE, Ingle JN, Ales-Martinez JE, Cheung AM, Chlebowski RT, Wactawski-Wende J, et al. Exemestane for breast-cancer prevention in postmenopausal women. N Engl J Med. 2011;364:238191.

[108] Ropka ME, Keim J, Philbrick JT. Patient decisions about breast cancer chemoprevention: a systematic review and meta-analysis. J Clin Oncol. 2010;28:3090-5.

[109] Donnelly LS, Evans DG, Wiseman J, Fox J, Greenhalgh R, Affen J, et al. Uptake of tamoxifen in consecutive premenopausal women under surveillance in a high-risk breast cancer clinic. $\mathrm{Br} \mathrm{J}$ Cancer. 2014;110:1681-7. 
[110] Hartmann LC, Degnim AC, Santen RJ, Dupont WD, Ghosh K. Atypical hyperplasia of the breast--risk assessment and management options. N Engl J Med. 2015;372:78-89.

[111] David N, Labbe-Devilliers C, Moreau D, Loussouarn D, Campion L. Lésions de métaplasie cylindrique atypique (MCA) diagnostiquées par macrobiopsies assistées par aspiration : opportunité d'une exérèse chirurgicale? J Radiol. 2006;87:1671-7.

[112] Guerra-Wallace MM, Christensen WN, White RL, Jr. A retrospective study of columnar alteration with prominent apical snouts and secretions and the association with cancer. Am J Surg. 2004;188:395-8.

[113] Bonnett M, Wallis T, Rossmann M, Pernick NL, Bouwman D, Carolin KA, et al, Histopathologic analysis of atypical lesions in image-guided core breast biopsies. Mod Pathol. 2003;16:154-60.

[114] Nasser S, Fan M. Does atypical columnar cell hyperplasia on breast core biopsy warrant follow up excision? (Abstract). Mod Pathol. 2003;15:36A.

[115] Brogi E, Tan L. Findings at excisional biopsy (EBX) performed after identification of columnar cell change (CCC) of ductal epithelium in breast core biopsy (CBX) (Abstract). Mod Pathol. 2002;15:29A-30A.

[116] Doren E, Hulvat M, Norton J, Rajan P, Sarker S, Aranha G, et al. Predicting cancer on excision of atypical ductal hyperplasia. Am J Surg. 2008;195:358-61; discussion 61-2.

[117] Sohn V, Arthurs Z, Herbert G, Keylock J, Perry J, Eckert M, et al. Atypical ductal hyperplasia: improved accuracy with the 11-gauge vacuum-assisted versus the 14-gauge core biopsy needle. Ann Surg Oncol. 2007;14:2497-501.

[118] Liberman L, Holland AE, Marjan D, Murray MP, Bartella L, Morris EA, et al. Underestimation of atypical ductal hyperplasia at MRI-guided 9-gauge vacuum-assisted breast biopsy. AJR Am J Roentgenol. 2007;188:684-90.

[119] Winchester DJ, Bernstein JR, Jeske JM, Nicholson MH, Hahn EA, Goldschmidt RA, et al. Upstaging of atypical ductal hyperplasia after vacuum-assisted 11-gauge stereotactic core needle biopsy. Arch Surg. 2003;138:619-22; discussion 22-3.

[120] Rao A, Parker S, Ratzer E, Stephens J, Fenoglio M. Atypical ductal hyperplasia of the breast diagnosed by 11-gauge directional vacuum-assisted biopsy. Am J Surg. 2002;184:534-7.

[121] Darling ML, Smith DN, Lester SC, Kaelin C, Selland DL, Denison CM, et al. Atypical ductal hyperplasia and ductal carcinoma in situ as revealed by large-core needle breast biopsy: results of surgical excision. AJR Am J Roentgenol. 2000;175:1341-6.

[122] Brem RF, Behrndt VS, Sanow L, Gatewood OM. Atypical ductal hyperplasia: histologic underestimation of carcinoma in tissue harvested from impalpable breast lesions using 11-gauge stereotactically guided directional yacuum-assisted biopsy. AJR Am J Roentgenol. 1999;172:1405-7.

[123] Cangiarella J, Guth A, Axelrod D, Darvishian F, Singh B, Simsir A, et al. Is surgical excision necessary for the management of atypical lobular hyperplasia and lobular carcinoma in situ diagnosed on core needle biopsy?: a report of 38 cases and review of the literature. Arch Pathol Lab Med. 2008; 132:979-83.

[124] Londero V, Zuiani C, Linda A, Vianello E, Furlan A, Bazzocchi M. Lobular neoplasia: Core needle breast biopsy underestimation of malignancy in relation to radiologic and pathologic features. Breast. 2008.

[125] Lavoue V, Graesslin O, Classe JM, Fondrinier E, Angibeau H, Leveque J. Management of lobular neoplasia diagnosed by core needle biopsy: study of 52 biopsies with follow-up surgical excision. Breast. 2007; 16:533-9.

[126] Renshaw AA, Derhagopian RP, Martinez P, Gould EW. Lobular neoplasia in breast core needle biopsy specimens is associated with a low risk of ductal carcinoma in situ or invasive carcinoma on subsequent excision. Am J Clin Pathol. 2006;126:310-3.

[127] Mahoney MC, Robinson-Smith TM, Shaughnessy EA. Lobular neoplasia at 11-gauge vacuumassisted stereotactic biopsy: correlation with surgical excisional biopsy and mammographic follow-up. AJR Am J Roentgenol. 2006;187:949-54.

[128] Hoover R, Glass A, Finkle WD, Azevedo D, Milne K. Conjugated estrogens and breast cancer risk in women. J Natl Cancer Inst. 1981;67:815-20. 
Table 1. Description of the 3 types of atypical hyperplasia of the breast: atypical ductal hyperplasia, lobular neoplasia (ALH/LCIS) and flat epithelial atypia.

\section{ADH \\ LN (ALH/ LCIS) \\ FEA}

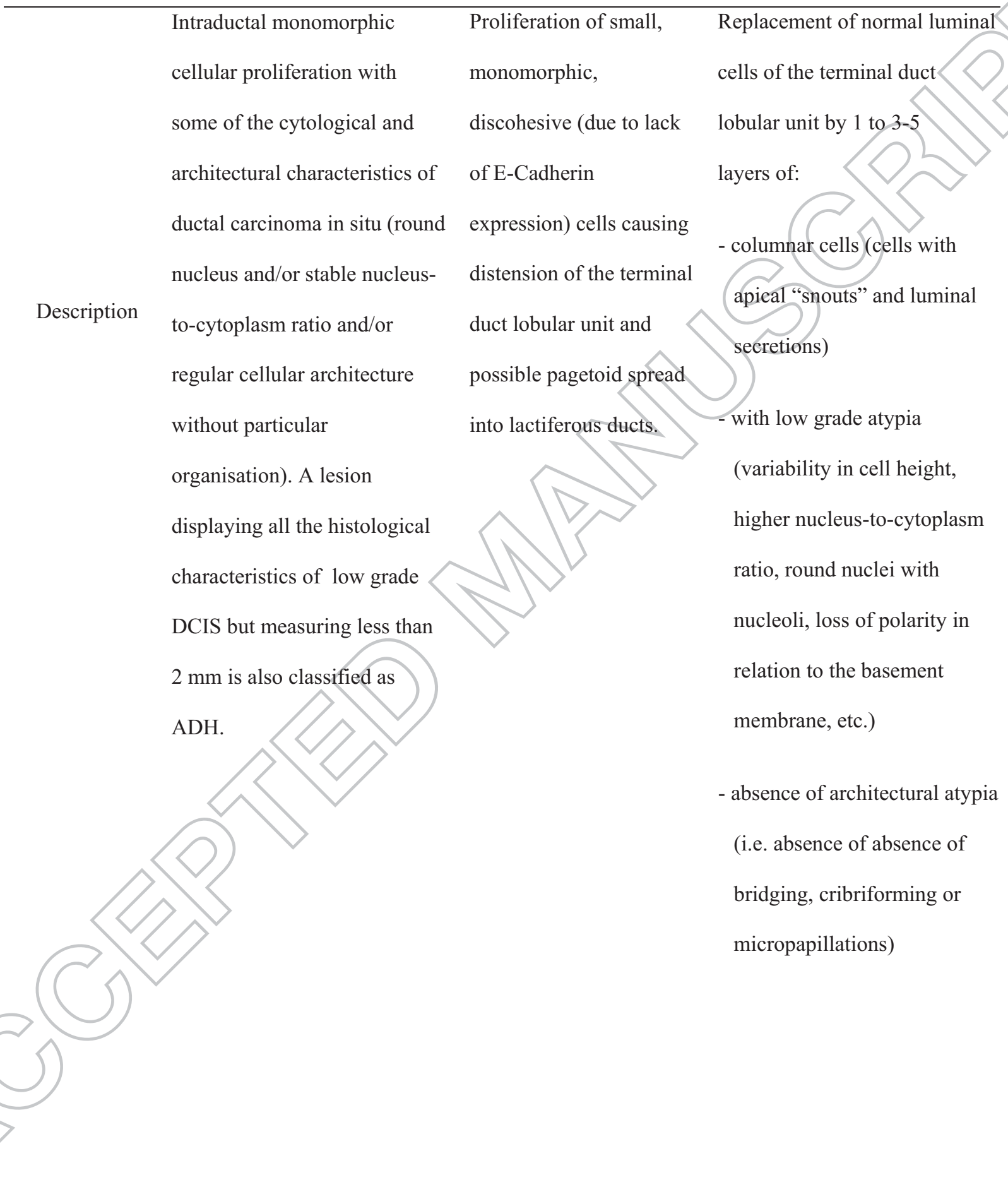


Immuno

histochemistry

34BE12 +/-

$\mathrm{ER}+$ and $\mathrm{PR}+$

CK 5- and CK18+

Incidence

$12 \%$

(/surgical

biopsies)

Mean age

Relative risk of breast cancer 4

46 years
E-cadherin -

34BE12+

34BE12 -

ER+ and PR+

low Ki 67

CK5- and CK18+

$7.8 \%$
$3.5 \%$

$\mathrm{ER}+$ and $\mathrm{PR}+$

low Ki 67

CK 5- and CK18+

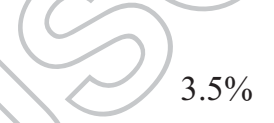

46 years

$?$
Surgical biopsy

( )

Clear margins not necessary
4.2

$?$

Surgical biopsy for LCIS Surgical biopsy could be avoided

Surgical biopsy could be

avoided for HLA

Clear margins not

necessary (except for

pleomorphic LN)
Surveillance

Clear margins not necessary

Surveillance 
Table 2. Pure flat epithelial atypia on percutaneous breast biopsy.

\begin{tabular}{|c|c|c|c|c|}
\hline & $\begin{array}{l}\text { Number of cases } \\
\text { with pure FEA on } \\
\text { percutaneous biopsy }\end{array}$ & $\begin{array}{l}\text { Number of follow-up } \\
\text { lumpectomies (\%) }\end{array}$ & $\begin{array}{l}\text { Number of DCIS } \\
\text { and/or IC discovered } \\
\text { on lumpectomy }\end{array}$ & $\begin{array}{l}\% \\
\text { underestimation }\end{array}$ \\
\hline $\begin{array}{l}\text { Kunju et al. } \\
(2007)[19]\end{array}$ & 14 & $14(100 \%)$ & 3 DCIS/IDC & \\
\hline $\begin{array}{l}\text { David et al. } \\
\text { (2006) [111] }\end{array}$ & 56 & $40(71 \%)$ & 7 DCIS/IC & \\
\hline $\begin{array}{l}\text { Guerra-Wallace } \\
\text { et al. (2004) } \\
{[112]}\end{array}$ & 39 & $31(79 \%)$ & & $13 \%$ \\
\hline $\begin{array}{l}\text { Bonnett et al. } \\
(2003)[113]\end{array}$ & --- & & 2 DCIS/IDC & $22 \%$ \\
\hline $\begin{array}{l}\text { Nasser et al. } \\
(2003)[114]\end{array}$ & 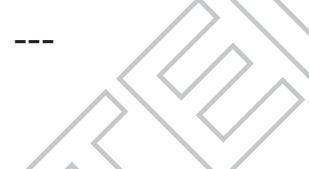 & $27(--)$ & 6 DCIS/IC & $22 \%$ \\
\hline Brogi & & $23(--)$ & 7 DCIS/IC & $30 \%$ \\
\hline
\end{tabular}

FEA: Flat epithelial atypia; DCIS: ductal carcinoma in situ; IC: invasive carcinoma; IDC: invasive ductal carcinoma 
Table 3. Pure atypical ductal hyperplasia on percutaneous breast biopsy.

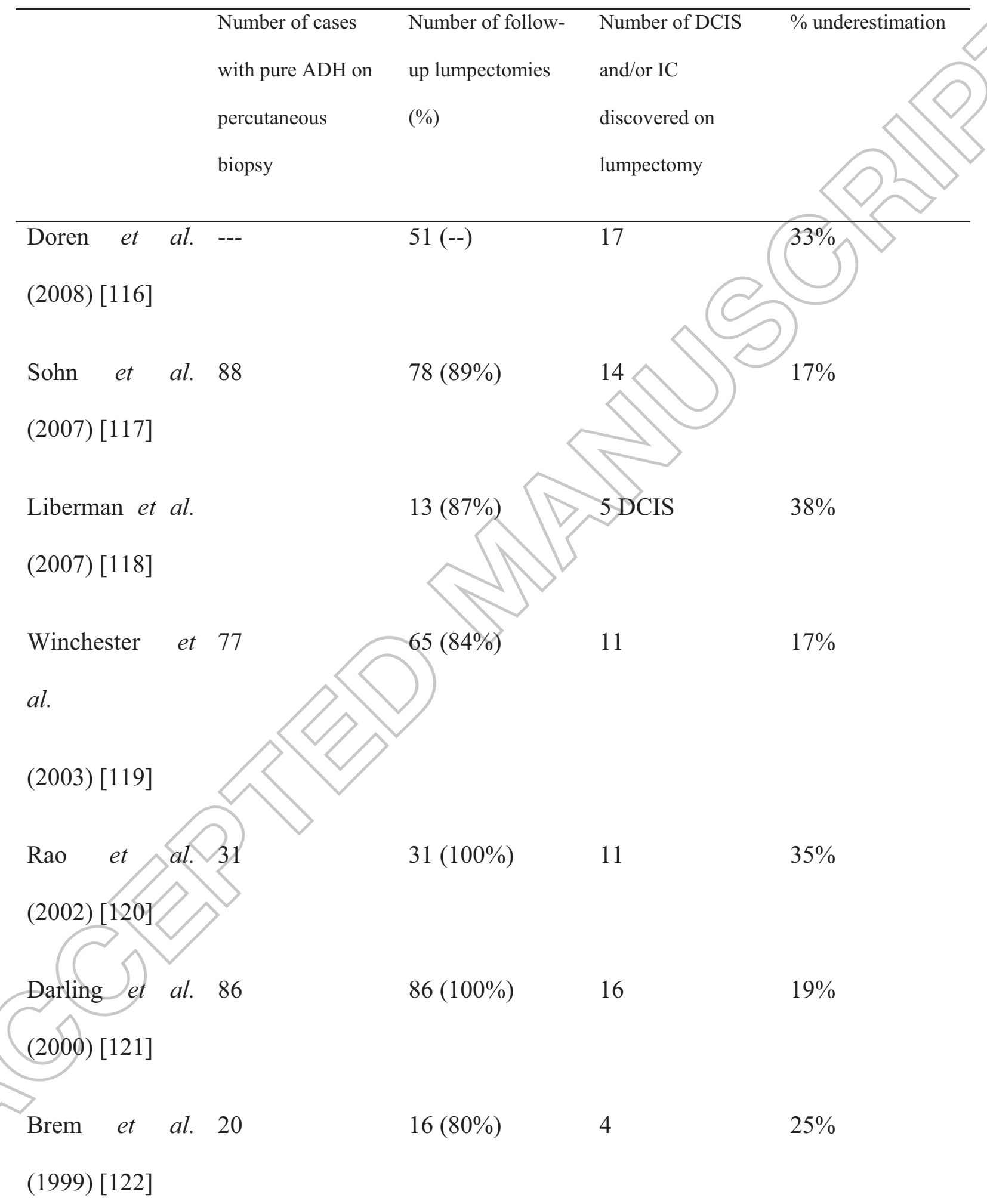

ADH: atypical ductal hyperplasia; DCIS: ductal carcinoma in situ; IC: invasive carcinoma 
Table 4. Pure lobular neoplasia on percutaneous breast biopsy.

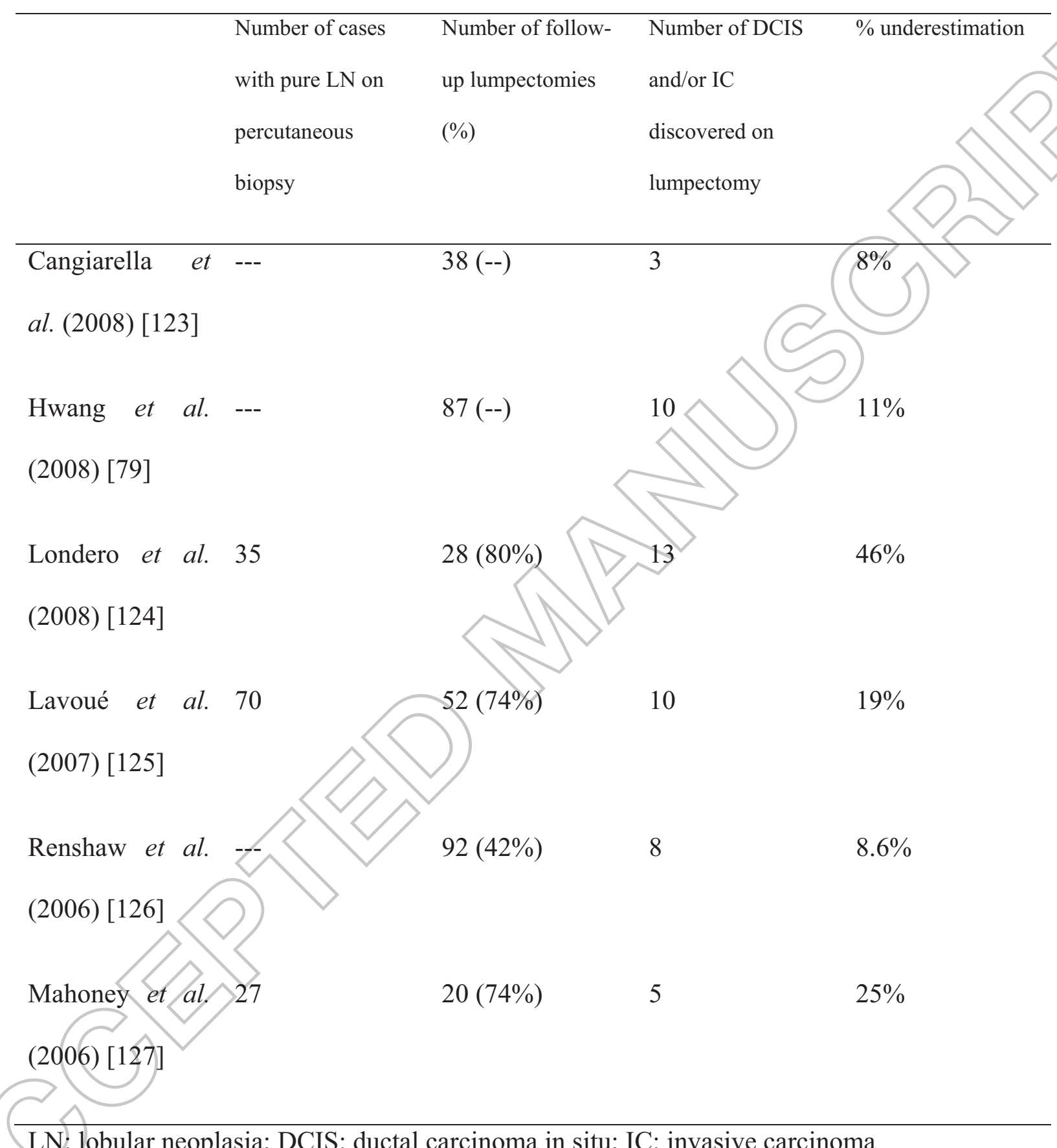


Table 5. Risk of benign proliferative lesions of the breast with or without atypia and use of hormone replacement therapy.

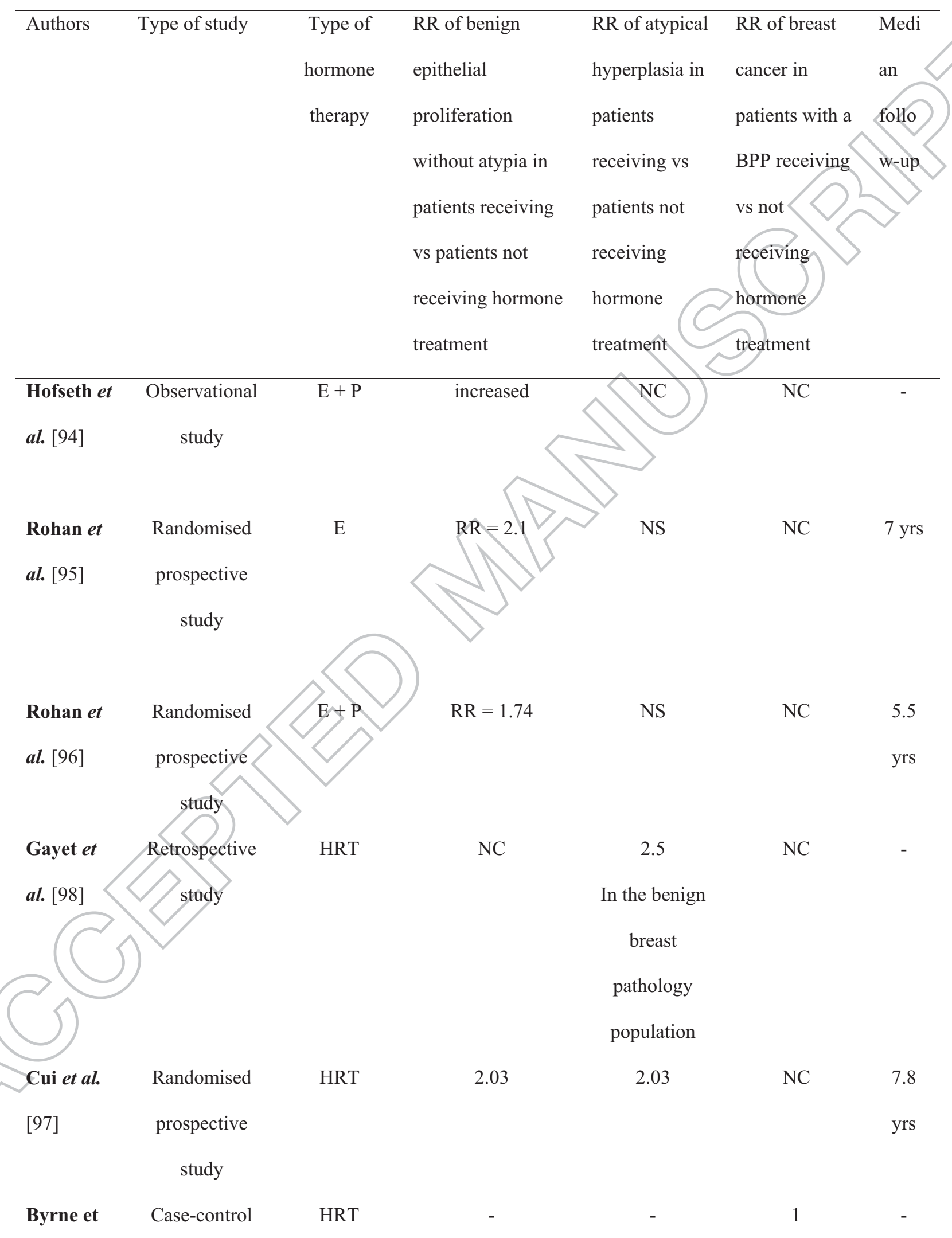


al. [104] study $\quad$ NS

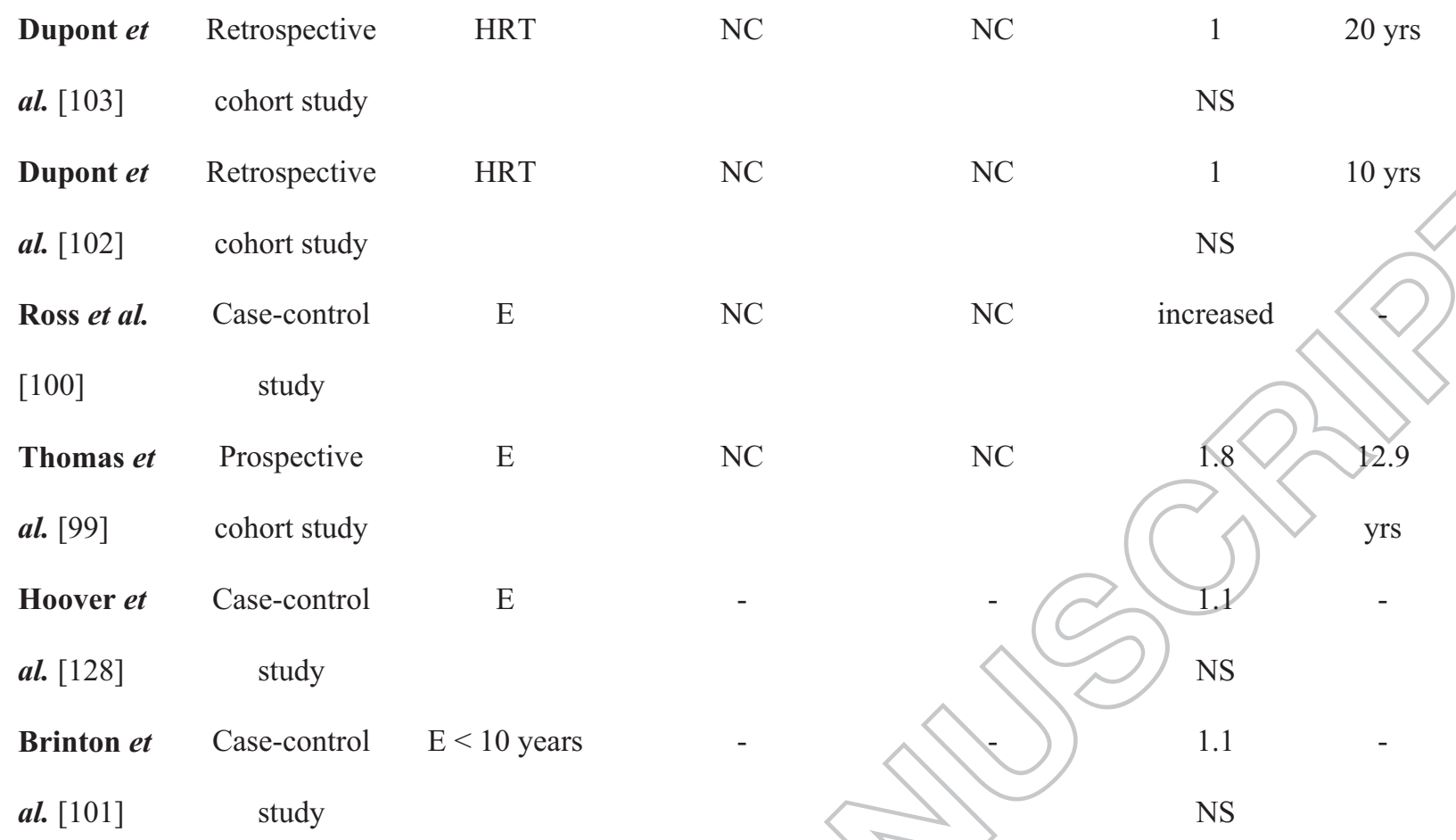

E: Oestrogen; P: Progesterone; NS: Not significant; NC: Not communicated; HRT: Hormone replacement therapy ( $\mathrm{E}$ or $\mathrm{E}+\mathrm{P}$ not distinguished in the studied group); $\mathrm{AH}$ : atypical hyperplasia of the breast; BPP: benign proliferative pathology of the breast. 